\title{
Flowstone growth in Gournier River (Vercors, France): a diachronic landscape analysis by 3D modelling and photo draping
}

\author{
Kim Genuite*, Yves Perrette, and Stéphane Jaillet \\ Université Grenoble Alpes, Université Savoie Mont Blanc, CNRS, EDYTEM, 73000 Chambéry, France
}

\begin{abstract}
Calcite surface has been reported by cavers and scientists over the last decades. Here, we present a methodological work aimed at quantifying that growth. We suggest a method of draping old photographs of a part of the Gournier Cave onto a 3D model. This work relies on a collection of photographs taken by cavers. We have chosen to study a site for which the maximum number of photographs was available. The series of photographs over time makes it possible to overcome the limitation of calcite crust dating. The acquisition of the 3D model has been achieved using terrestrial LIDAR. Then, photographs were draped over this 3D model to digitize the calcite/limestone limit. The four pictures that were used span the 1950 to 2014 growth period. We demonstrate that the growth began before 1964 and that it is not directly related to an airflow increase in the cave due to the opening of a sump by cavers in 1992. The surface increase is ascribed to regional changes, but we cannot ascertain whether climatic or environmental controls are its main drivers. Furthermore, it remains uncertain whether an acceleration of calcite growth was driven by local changes induced by an increase in airflow.
\end{abstract}

Keywords: $\quad$ flowstone, geomorphology, 3D, photo draping, global change

Received 31 January 2017; Revised 13 December 2017; Accepted 13 December 2017

Citation: Genuite K., Perrette Y. and Jaillet S., 2018. Flowstone growth in Gournier River (Vercors, France): a diachronic landscape analysis by $3 \mathrm{D}$ modelling and photo draping. International Journal of Speleology, 47 (1), 81-91. Tampa, FL (USA) ISSN 0392-6672 https://doi.org/10.5038/1827-806X.47.1.2116

\section{INTRODUCTION}

Among speleothems, little attention has been paid to subaqueous flowstones because their complex genesis and diagenesis make U/Th dating difficult (Ortega et al., 2005). However, they are generated by karstic flows and are supposed to record changes on a whole-watershed scale. In various areas, cavers have reported new growths in subterranean rivers.

The Gournier Cave is one such cave. G. Marbach (a caver), reported on the evolution of the carbonate deposits at the cave by comparing two of his own photographs over time (Fig. 1).

From this initial observation, we propose a method to ascertain and quantify calcite growth based on the comparison of photograph sets. Previous similar methods have been successfully utilised to demonstrate landscape evolution using photographs combined with digital elevation models (DEM) (Bozzini et al., 2013; Scapozza et al., 2014). These studies have shown that such a method needs to integrate two features: the availability of a large set of photographs; and the ability to quantify calcite surfaces, taking into account the topography.
We report here the application of this method on one site in the Gournier Canyon (Vercors, France).

The Gournier Cave displays both these traits. On the one hand, the Gournier Cave has been regularly visited since its discovery, which provides the opportunity to test the proposed method based on the large quantity of photographs generated by cavers over time since 1950. On the other hand, the technique of coupling of 3D topometric surveys with improved mathematical methods designed to cover and reshape photographs onto numerical topographic models is well designed to quantify calcite surfaces (Bozzini et al., 2011).

\section{CALCITE CRUST IN THE GOURNIER SUBTERRANEAN RIVER}

\section{Geological settings of the Gournier Cave}

The Gournier Cave is located near Grenoble in the Vercors Range, which is part of the Prealps $\left(45^{\circ} 04^{\prime} \mathrm{N}\right.$, $5^{\circ} 23^{\prime} \mathrm{E}, 570 \mathrm{~m}$ asl). Next to the Choranche touristic cave (Perrette \& Jaillet, 2010), Gournier contains $17 \mathrm{~km}$ of passages and shafts within the massive Urgonian Limestone Formation (Arnaud-Vanneau et al., 1976). 

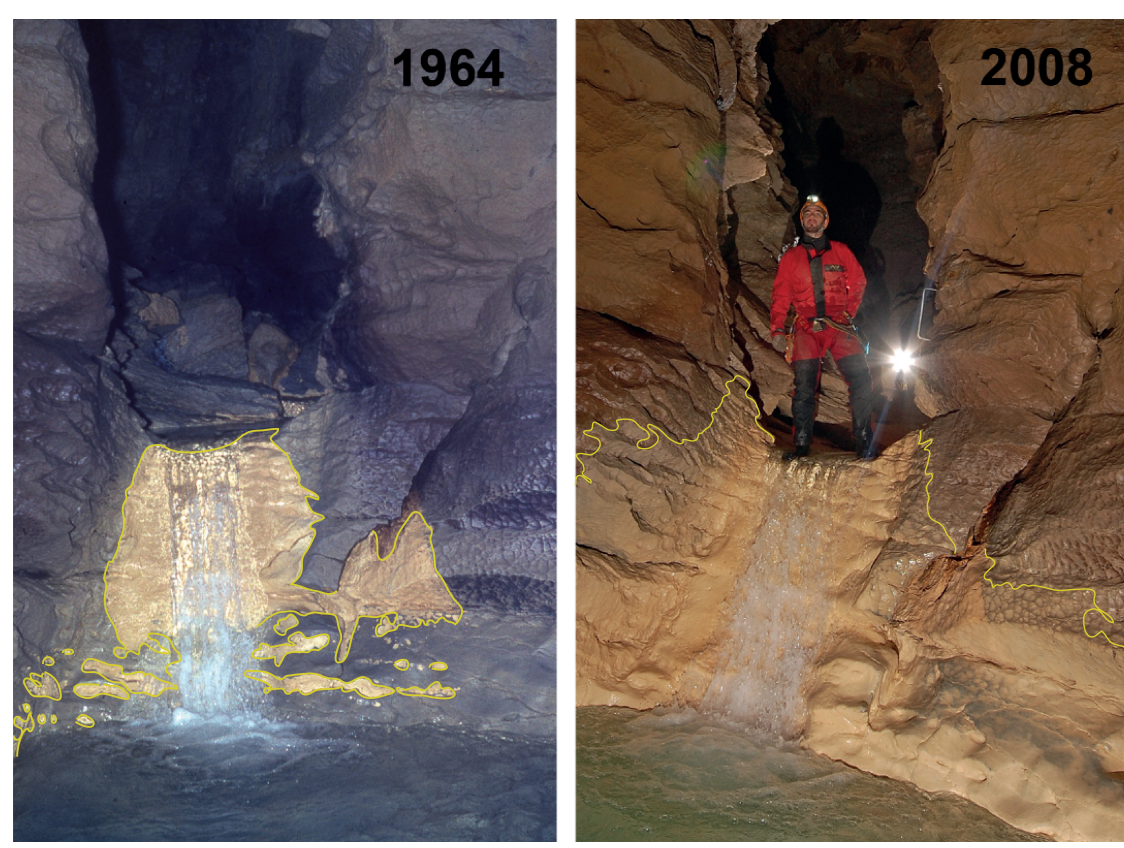

Fig. 1. Comparison of subterranean flowstone growth in the second waterfall of the second access (see Fig. 2); calcite crust contour is digitised in yellow. The bright calcite deposit contrasts with the darker limestone, making it easy to visually determine the deposit's limits in photographs.

The Gournier karstic spring drains from the "Plateau des Coulmes" (at 800 to $1,400 \mathrm{~m}$ asl). Used since $1400 \mathrm{AD}$ for wood charcoal production, the previously cleared environment was progressively reforested following the reduction of this activity from the end of the $19^{\text {th }}$ century until its complete halt at the midpoint of the $20^{\text {th }}$ century (Perrette et al., 2008). At present, $73 \%$ of the $7 \mathrm{~km}^{2}$ watershed is covered by beech forest in the foothill zone, $13 \%$ is covered by mixed forest in the mountain zone (beeches and spruces), and the remaining $14 \%$ is covered with grassland and agricultural areas.

Karstification in the Gournier area follows the south dip of the less permeable Hauterivian marl strata (Fig. 2), leading to a vadose karst that drains the $1,400 \mathrm{~mm}$ of annual meteoric water to the Bourne river. Unpublished time series measurements by the "Environment, Dynamics, Territories and Mountain Laboratory" (EDYTEM) laboratory since 1997 show that this karst spring responds in less than 6 hours to rainfall and snow cover melting. The base flow has been estimated at approximately $401 \cdot \mathrm{s}^{-1}$; strong discharges exceed $3 \mathrm{~m}^{3} \cdot \mathrm{s}^{-1}$. From the entrance, the first kilometre of Gournier Cave follows an underground river with fossil passages, active canyons and waterfalls.

After the initial exploration of the cave in 1948, a perched sump (Siphon Jérôme) was destroyed in 1992 by the breaching of the dam by cavers. That opening made the explorations easier and led to a local increase in ventilation (Lismonde, 2002), which could have resulted in increased calcite saturation as well.

As characterised in 1980, running water at the site holds a temperature ranging from 7.5 to $8.5^{\circ} \mathrm{C}$ and a mean dissolved calcium concentration of 186 $\mathrm{mg} \cdot \mathrm{l}^{-1}$ (Delannoy, 1982). The cave is well decorated in the fossil passages and in the subterranean canyon. The calcite saturation is increased by degassing processes that occur along waterfalls of the subterranean canyon.

\section{Calcite crust description}

Calcite crust can be observed on the walls in the canyon of the Gournier Cave and resembles a yellowto-orange travertine-like material that strongly contrasts with the darker bedrock (Fig. 1, Fig. 3). Four samples have been cored in the river section in the Gournier Canyon near the waterfall of the second access. During the winter of 2014, sampling was achieved in the riverbed upstream from the waterfall. Figure 3 shows a typical calcareous tufa fabric as proposed by Frisia et al. (2000), which is associated with highly variable discharge and dry periods during the low water period. Laminations can sometimes be seen in the samples (Fig. 3), but the architecture of the laminae makes it difficult to ascertain whether the laminations are annual.

These calcite fabrics are generally associated with supersaturation over 0.5 saturation index (SIc) and can be found in passages where the temperature fluctuates (Frisia, 2015).

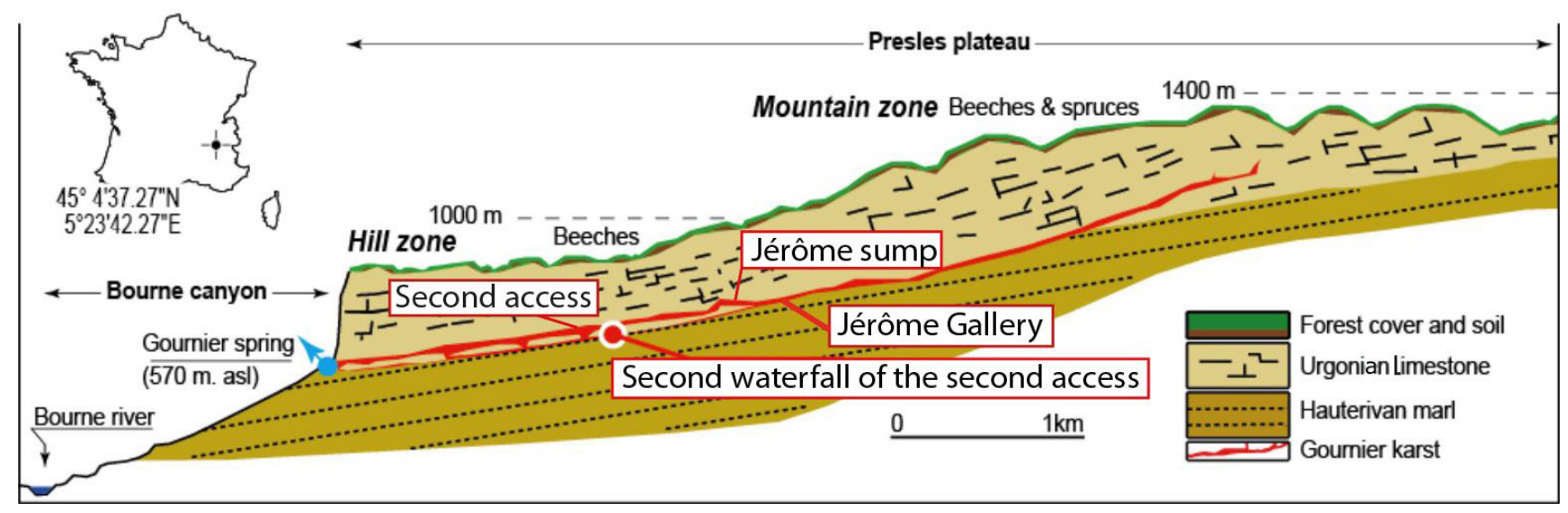

Fig. 2. Gournier's location. The karst follows the Hauterivian marl and water runs through a forest that grows atop the massive Urgonian Limestone Formation. The studied area is a waterfall located at the beginning of the subterranean canyon, after a one hour walk into the fossil cave. It is often photographed by cavers because of its accessibility, being located at one of the two main entrances of the subterranean canyon. Topography modified from Delannoy et al. (1988). 


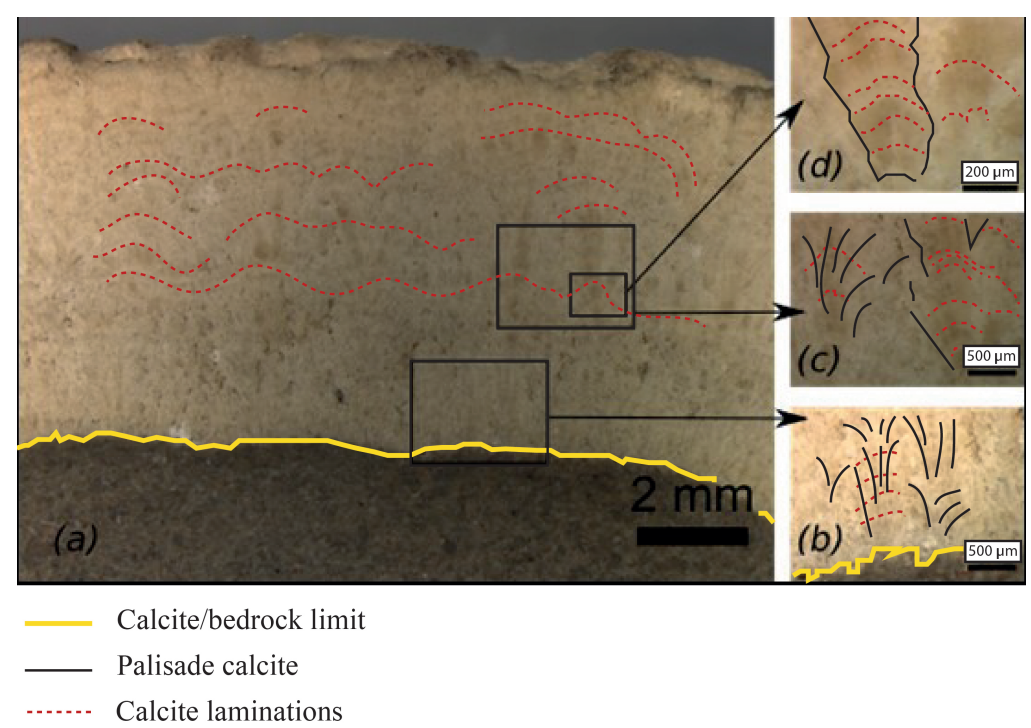

Fig. 3. Section of the crusts. (a) Overview of the homogeneous tufa fabric deposited on Urgonian Limestone; (b)-(c) laminations in compact zones; (d) magnification of the (c) zone showing a nested lamination. The contrast between carbonate deposits and limestone allow the calcite from the limestone regions to be readily distinguished in photographs.

Calcite growth can be seen into the waterfall but also in the riverbed and on both sides of the canyon. However, the limestone tablets in the underground stream show a gain of mass per surface area of approximately $5 \cdot 10^{-4} \mathrm{~g} \cdot \mathrm{mm}^{-2} \cdot \mathrm{y}^{-1}$, which corresponds to a vertical growth of $180 \mu \mathrm{m} \cdot \mathrm{y}^{-1}$ (Delannoy, 1982). The same observation can be made at the Choranche Cave, $1 \mathrm{~km}$ from the sampling site. Measurements of calcite deposits on a climbing mast erected during the 1954 explorations of Choranche indicate a slightly higher calcite deposition rate but at a similar magnitude ( $25 \mathrm{~mm}$ over 50 years, i.e., $500 \mu \mathrm{m} \cdot \mathrm{y}^{-1}$ ) (Perrette et al., 2015). The measurements (Fig. 3) of calcite crusts sampled a few meters near the study site indicate that they are within same range of thickness. This result confirms that the carbonate deposits in Gournier are relatively recent in occurrence. Despite the calcite crust's thinness (ranging from 0.2 to $8 \mathrm{~mm}$ ), its bright colour strongly impacts the cave scenery.

\section{METHODS}

\section{Methodological strategy}

Photograph collection and analysis

We collected photographs of the Gournier Canyon taken from 1950 to 2014. The use of mailing lists, scientific and caving magazines, private collections and online publications of expeditions facilitated the collection of a large quantity of pictures (Fig. 4). Photographs were selected according to their suitability for this study: we needed well-exposed and sufficiently detailed pictures of the canyon, which were saved into a database.

Our collection of 148 photographs is composed of:

- 41 slides from private collections (slides that were scanned).

- 20 pictures published in speleological publications (Spéléo magazine, Scialet, Spelunca) (photographs scanned from publications).

- 89 pictures from expeditions published online (obtained directly from the internet).
Regarding the 4 photographs used for the comparison, the 1950 photograph was scanned from a publication (Bourgin, 1950), the 1964 and 2008 photographs were scanned from slides, and we took the 2014 photograph. For each selected site, a photograph was taken during the winter of 2013/2014 to complete the collection. Each photograph was implemented in a database with complementary data such as "presence of calcite deposition in the cave". These data were used in order to determine a global estimate of the repartition of calcite over time and space.

Figure 4 illustrates the distribution of the collected photographs over time and along the topography of the Gournier Cave. Photographic coverage was obtained for most parts of the Gournier Cave.

\section{Selection of the waterfall site}

To estimate the growth rate of a calcite crust using photographs, a sufficient database needs to be compiled for a site of interest. Our strategy was to initially gather a large photograph collection covering the entire cave from the speleological community. From that preliminary collection, 9 sites were chosen within the first kilometer from the entrance of the cave based on two criteria: the sites should have photographs older than 1980, and those photographs should be sharp. From the assembled database, the most documented site was selected for testing with our method: a waterfall with photographs taken from 1950 (Bourgin, 1950) onward.

Following previous methods used by Grussenmeyer et al. (2010), Ravanel \& Deline (2011), Bozzini et al. (2013), and Ployon et al. (2014), we compare photographs of the waterfall site by drawing with CAD software the borders of the carbonate deposit in the photographs, and the borders are readily distinguished thanks to the contrast between the bright calcite and the darker limestone. Unfortunately, given the diversity of the photographs, surfaces cannot be directly compared because of the changes in viewpoints and scales.

\section{Photo draping}

Recently developed 3D technologies (Jaillet et al., 2011a) allow researchers to overcome the aforementioned limitation of visual photograph comparison. Because these technologies require strong investment in data collection in the field and in data post-processing, we focused the photo draping application on only one site: the second waterfall of the second access of the Gournier Cave.

The general principle is to drape a photograph onto a 3D topography in order to determine the X, Y, and $Z$ Cartesian coordinate system of each pixel. This flat metric system was not projected in a terrestrial coordinate system.

As a first step, we used a laser scanning method to produce a point cloud (Canevese et al., 2013). Eleven scans were acquired with a FARO Focus 3D 120 scanner which has a distance accuracy up to $\pm 0.002 \mathrm{~m}$, 


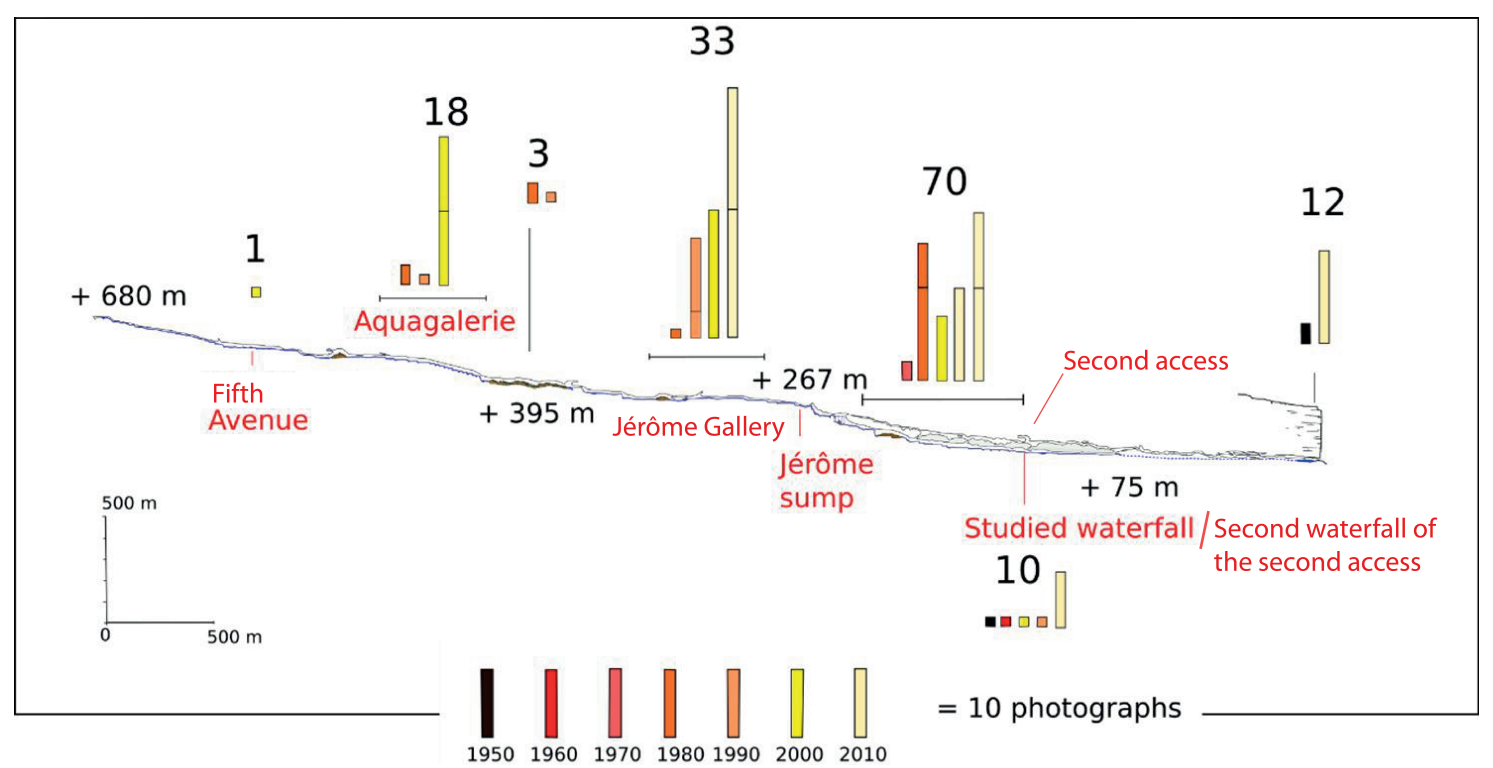

Fig. 4. Location of photographs taken in Gournier over time. Each bar represents a number of photographs. Different colours identify decades. The data clearly show an increase in the number of photographs over time: most of the available photographs were taken recently and mainly in the lowest part of the Gournier Canyon (in altitude asl). It is also apparent that studied waterfall is the only waterfall amenable to a landscape analysis based on more than two photographs. Topography modified from Caillault (2000).

range from $0.6 \mathrm{~m}$ up to $120 \mathrm{~m}$, and noise reduction by $50 \%$ ), (Oludare Idrees $\&$ Pradhan, 2016; FARO ${ }^{\mathrm{TM}}$ ). Spherical targets are located in the cave before laser scanning in order to facilitate the rebuilding of the complete point cloud from the different acquisition scans by using the SCENE software $\left(F A R O^{T M}\right.$ ) (Hajri et al., 2009; Canevese et al., 2013; Gallay et al., 2015). According to the instrument specification, $\left(\mathrm{FARO}^{T M}\right)$, the point cloud accuracy is approximately $0.002 \mathrm{~m}$. However, as the laser scanning is done in a wet environment, the laser beams can be reflected by water, leading to an increase in the difference between the point cloud and reality; and a loss of points during acquisition (by approximately 5\%) (Jaillet et al., 2011a). The problem is also manifested at the waterfall: the water flow inhibits the determination of the subaqueous topography by laser scanning, and the subaqueous surface is not visible in photographs. Those points have been deleted in the final point cloud with visual control. The final point cloud representing the waterfall contains 344,256 points, with a $0.015 \mathrm{~m}$ definition. The 3D numerical model of the waterfall has been generated using 3DReshaper ${ }^{T M}$ meshing functions (Hajri, 2010). We have generated a Delaunay triangulated model (Delaunay, 1934) with regular triangles (all similar in size), which reveal 0.032-m details. This resolution was well adapted to our goal.

On the waterfall zone, 10 measurements between the point cloud and the mesh were achieved manually with the 3DReshaper measuring tool. A mean distance of $0.005 \mathrm{~m}$ (Fig. 5) was considered for uncertainty assessment. Only one 3D model has been built because we assume that the 3D topographic changes of the bedrock can be neglected over the time spanned by the study. Indeed, from 1950 to 2014, the calcite crust spread all over the waterfall. However, the deposit remained thin, having a thickness of less than $0.01 \mathrm{~m}$ according to our observations on samples taken around the second waterfall of the second access (top and bottom of the waterfall - Fig. 2), which is smaller than the $0.032 \mathrm{~m}$ mean triangle size of the model (Fig. 5).

Thus, the photo draping process was applied to the upper part of the calcite visible in the photographs. The 2014 photograph of the waterfall was used to define the spatial limits of our study because of its sharpness.

The accuracy of the photographs allowed us to drape them with less than $0.032 \mathrm{~m}$ of uncertainty, calculated by measuring the difference on topographic edges, both on the mesh and on the photographs (Fig. 5). This means that the triangles of the $3 \mathrm{D}$ model are larger than the uncertainty of the photo draping process for all four photographs used, and of the "texels" (stretched pixels on the 3D model; Fig. 5) of the draped photographs. Fortunately, the sharp topography of the waterfall area favoured the quality of photo draping and therefore served as its quality control, as it was possible to see if the sharp edges visibles on the photograph were corresponding to the ones onto the 3D model. A few tries were most of the time necessary before the final validation by visual control.

We used 3DReshaper ${ }^{T M}$ (Jaillet et al., 2011b; Battaglia, 2015) to drape our photographs onto the triangulated model. The draping process involves the creation of a table that attaches typical points from a photograph to points in the 3D model, functioning in the same way as georeferencing and photo draping processes for 2D and GIS software (Bozzini et al., 2011; Ployon et al., 2014).

The operator manually chooses the points on the 3D model and picks a corresponding point on the photograph. Following the different points, the photograph is stretched to fit the 3D topography. After creating 10 to 20 points, the photograph is draped onto the surface. The draping allows for the construction of a 3D image and the display of a photorealistic texture on the triangulated model. This process takes time and is highly influenced by the positions of the points. 


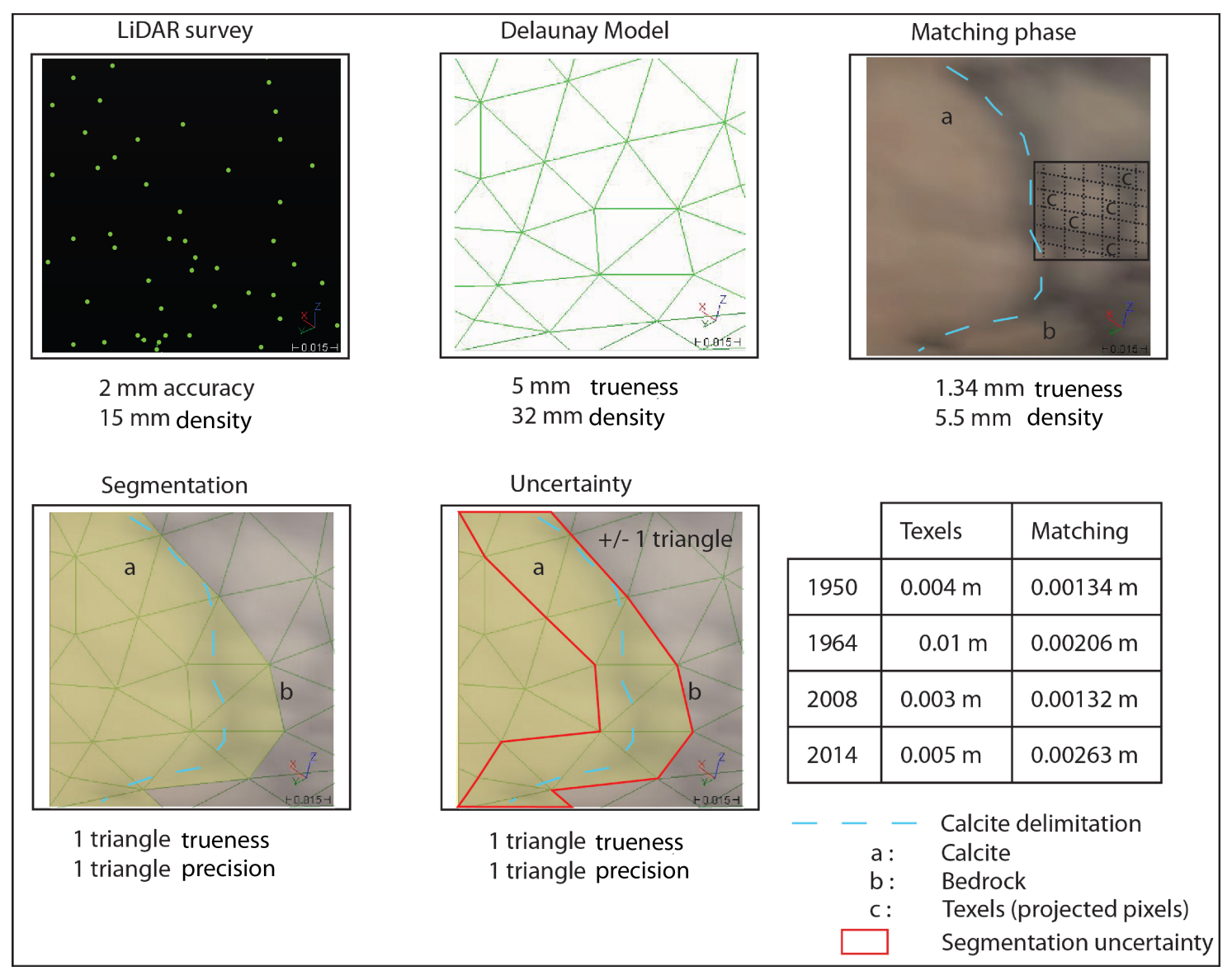

Fig. 5. LIDAR survey, meshing process and the calculation of the uncertainties. Considering: i) the uncertainty produced by the mesh construction; ii) the photo draping and iii) the digitising process, the matching uncertainty reaches $2.6 \mathrm{~cm}$ for the 2014 photograph. It is smaller than the mean $0.032 \mathrm{~m}$ triangle size of the mesh. Consequently, because of the resolution that was used for the mesh, the cutting process generates larger uncertainties than the draping method.

An ideal 3D photo draping should be built with points regularly placed over the entire picture, but the topography and resolution of a given photograph do not always allow for such conditions. Hence, points are only placed when the operator is confident with the correspondences between the photograph and the 3D model. In our case, the topography is clearly visible even on the older photographs (1950 and 1964), so the topographic details helped in the generation of a decent photo draping (Fig. 5). We took 20 measurements for each photograph, measuring the difference between the 3D model sharp topographic details and the visible details in the photograph. This provided a measure of the global uncertainty of the draping process. The good resolution of the mesh resulted in a global draping uncertainty value of less than $2.6 \mathrm{~cm}$ (highest uncertainty value, obtained on the 2014 photograph stretching, Fig. 5) including measures of trueness and data processing precision based on measurements taken on the bare canyon walls (considered to be stable).

\section{RESULTS}

As expected, the number of suitable photographs increases with time and decreases with distance from the entrance (Fig. 4). As such, there is a considerable quantity of data dating from 1980 to the present, and substantially fewer pictures dating from between 1950 and 1980. Despite the smaller quantity of older pictures, the collection is sufficient in space and time to observe a calcite crust progression in different parts of the cave.

\section{Photographic observations}

Calcite crust was observed along the canyon on all photographs. We managed to compare photographs taken recently with older photographs of the lower part of the canyon. Several comparisons were possible between at least 2 photographs taken at the same place and, with similar viewpoints (Fig. 7). Moreover, in the most recent photographs, including our own 2014 coverage, a highly regular deposit can be observed along the whole canyon. The upper border of this calcite crust follows the waterline above the low flow level. Generally, the distance between this upper calcite lining and the low water level is approximately $0.3 \mathrm{~m}$, but this is highly dependent on the canyon section, and it can exceed $1 \mathrm{~m}$ in the larger sections. The relation between distance of the calcite lining and the low water level and with the cave passage seems to be controlled by flow rates.

From a temporal viewpoint, an increase in calcite crust deposition can be observed between the 50s and the $80 \mathrm{~s}$ in the upper part of the canyon (in altitude asl) and also looks thick (e.g., the Jérôme drain and in the Fifth Avenue). The increase seems less important in the lowest part of the canyon in altitude asl (first waterfall of the second access, Jérôme Gallery) which means that either the upper part received an earlier deposit or a more substantial one. 

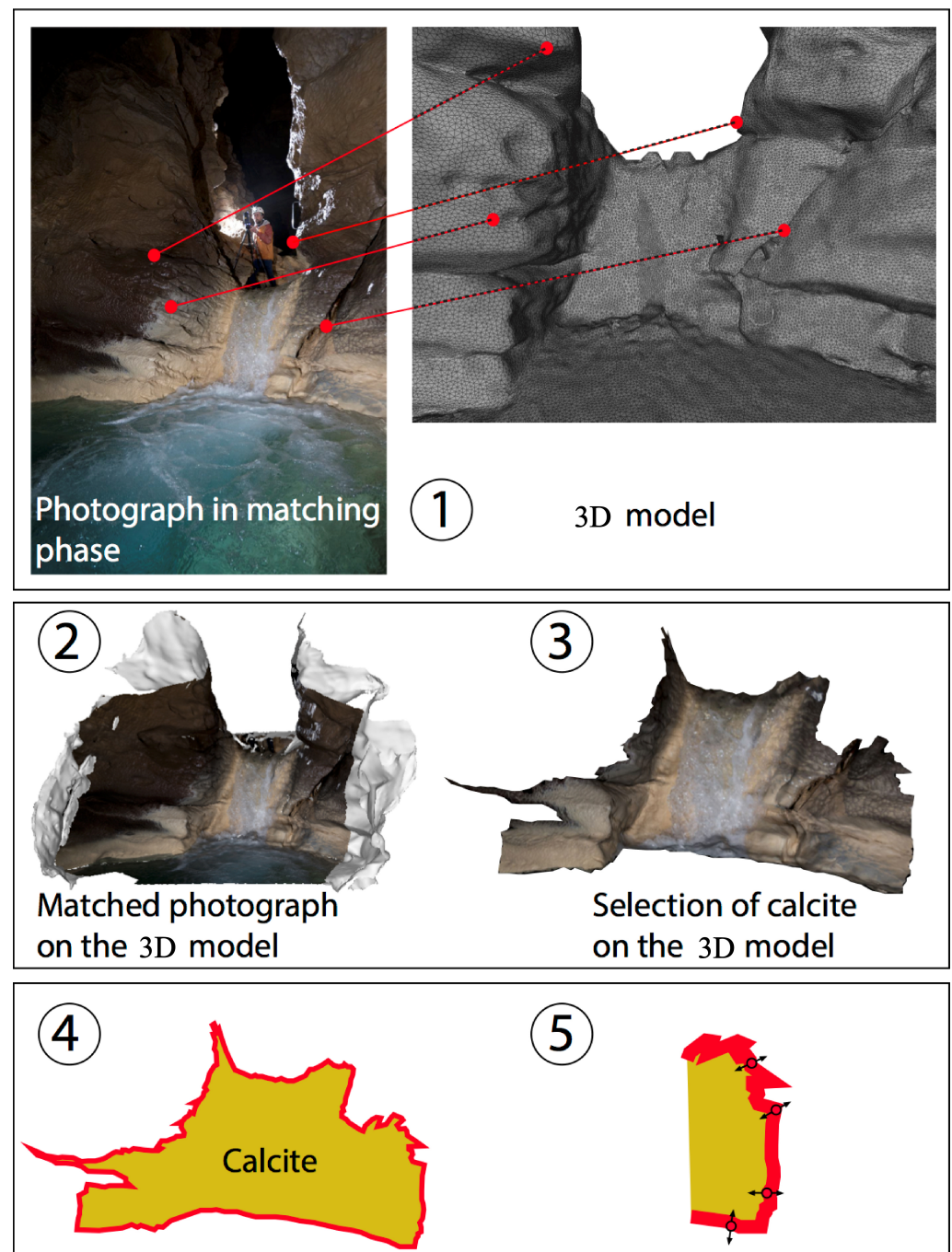

Surface measurement
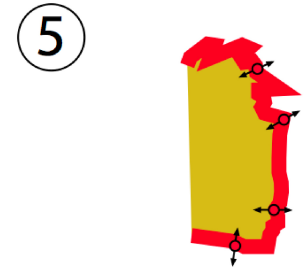

Uncertainty of measurement

Fig. 6. Photo draping method applied to Gournier's waterfall surface area. After a manual selection of corresponding points on both triangulated model and photographs, the software reconstructs the position where the photograph was taken and then drapes it onto the 3D model (Phase 1). The data is stretched onto the 3D model, recreating the texture using the topographic information given by the 3D model (Phase 2). The calcite contours are then directly cut through the 3D model using the mapped photograph that guides the operator through its cutting (Phase 3). The cut follows the triangles of the mesh (Phase 4), generating an uncertainty of quantification of \pm 1 triangle along the full length of the perimeter of the cut (red perimeter and black arrows - Phase 5).

According to cavers' observations (oral testimonies), this carbonate deposit seems to have appeared on the canyon walls around the year 1980 .

\section{Quantification}

Cutting through the 3D model to spatially delimit the calcite crust generates greater uncertainty because the 3D software (3DReshaper ${ }^{T M}$ ) only cuts according to the triangles' mesh sizes and spatial distributions (Fig. 5).

On the triangulated model, all the triangles have approximately the same size, but not exactly. As the software cuts according to the triangles, a mean triangle is determined and constitutes the smaller cutting unit for all four cuts.

As reported in Figure 8, The perimeter of the cuts is used to determine the global uncertainty of measurement: the perimeter is divided by the mean triangle size $(0.032 \mathrm{~m})$, then the surface area of the

calcite is divided by the number of triangles. This process yields the mean number of triangles that constitute the perimeter.

Then, the measured surface of the calcite is divided by the real number of triangles that represent the calcite crust, which yields the mean surface of the triangles.

Finally, we multiply the mean surface by the number of triangles found in the perimeter, which yields the uncertainty for each cut.

For the 1950 photograph, Fig. 9 shows the boat and the explorers hiding the right part of the waterfall. Considering that most of it was still visible, we digitized the masked areas using the 1964 contours for the masked area behind the caver and the boat, considering that the caver was hiding a part of the waterfall that was not covered with calcite crust in 1964, but which did not seem to be covered with it in 1950 according to the morphology of its visible part. The sharp topography of the waterfall area allows for a check on the quality of the photo draping.

The digitising of the calcite crust was favoured by the contrast between the light calcite and the dark limestone, which allowed for an accurate delineation of the upper boundary for each photograph with visual control.

Figure 9 shows the evolution of the carbonate deposit over time for our study site. The bright calcite surface increased from $2.0 \mathrm{~m}^{2}$ in 1950 to $7.2 \mathrm{~m}^{2}$ in 2014 . Calcite growth is significant at each stage and far exceeds the overall uncertainties. A slight acceleration of the deposition rate seems to appear between the 1964 and the 2008 photographs. However, because of the lack of photographs in the intervening time period and the uncertainty of the calcite surfaces, we cannot ascertain the time at which the acceleration occurred as the uncertainty is too substantial.

\section{DISCUSSION}

\section{About the methodology}

Working with historical data imposes some challenges with respect to data acquisition and interpretation, and requires that the study methodology be tailored to the data available. For example, the studied photographs are not taken under identical light conditions (especially the 1964 one: calcite crust highly contrasts with bedrock but some bedrock parts appear brighter because of the flash. Those areas were not considered as calcite as the same kind of colour can be found higher on the canyon walls, on the photograph), nor from the same viewpoint; and some photographs only provide partial coverage of study areas (e.g., the 1950 photograph is partly obstructed by a boat). Consequently, this introduces some uncertainties which limit the robustness of our approach. Further, in this study, the calcite was delineated visually, which was possible because the contrasts between calcite and bedrock were generally 

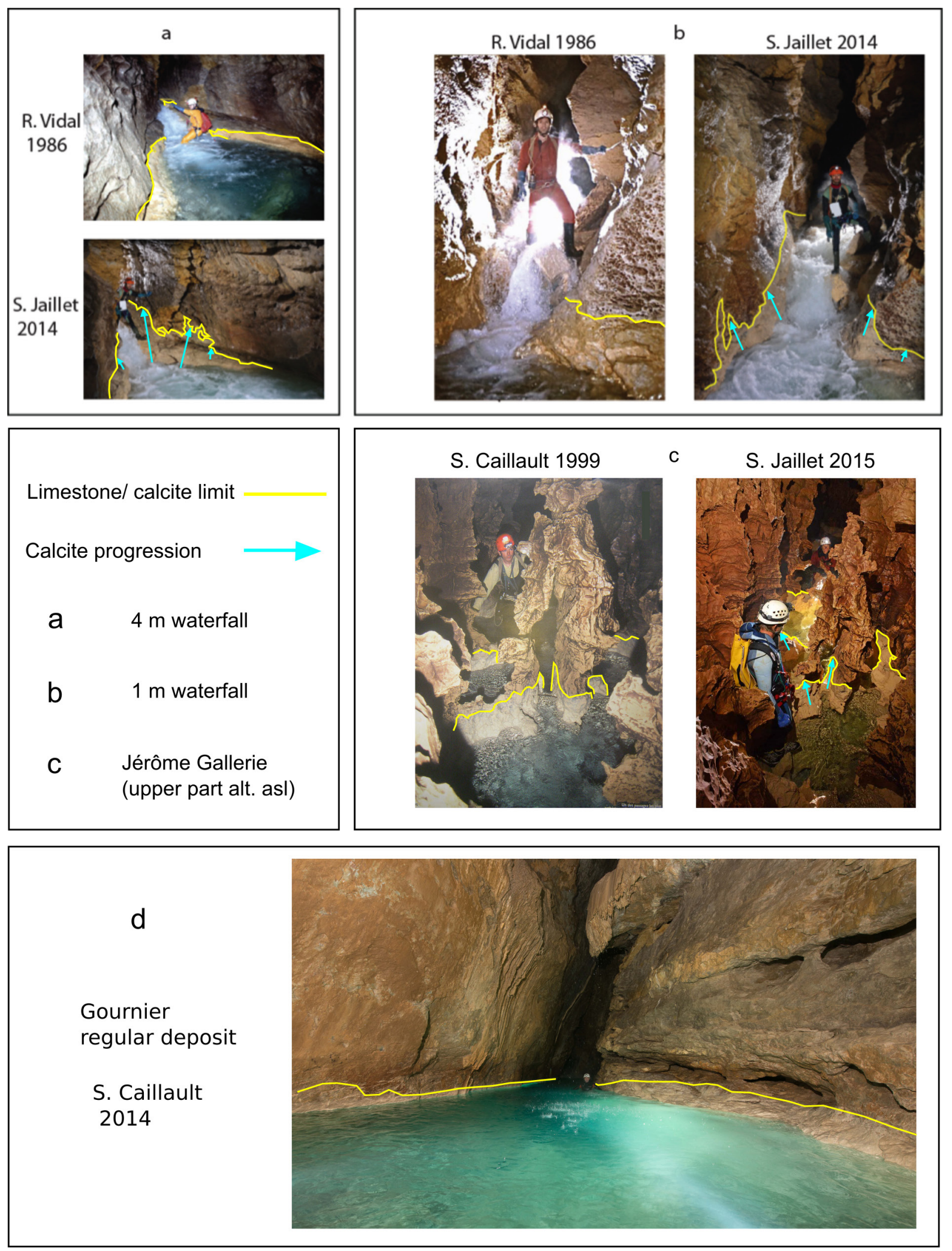

Fig 7. Photograph comparisons in the first part of the Gournier Canyon (in altitude asl). The growth of the calcite crust is clearly visible on the three sites. The (d) photograph (taken during low flow period) reveals how the deposit looks like in the flat parts of the karstic system.

strong. However, this introduces some uncertainties. For example, on the older photographs, the contrast between calcite and bedrock is very strong, however the boat prevents us from interpreting the calcite shape behind it. We used the 1964 calcite shape to complete it because it is the closest data we have, historically speaking, which provides the best possibility of a correct interpretation of the morphology of the calcite. For the more recent photographs (2008 and 2014), delineation uncertainties are also present, especially on the left side of the waterfall. This is a place where the calcite is patchy; sometimes it covers the entire bedrock, and in others, the bedrock is still visible. Although the patchy nature of the calcite here is not taken into account in the final cut of the 3D model (the mean triangles are bigger), the flashes used during the photographs, especially on the 2008 one, add too much uncertainty to be sufficiently sure about our delineation. Nevertheless, the increase through time is clear (Fig. 10). 
Although LIDAR is clearly the best solution for topographic scanning because it respects the geometry of scanned objects (Wandinger, 2005; Oludare Idrees \& Pradhan, 2016), it remains expensive and is not always affordable by research labs or the caver community. Furthermore, because of the absorbance of laser light by water, the LIDAR technique prevents us from acquiring the topography of a subaqueous environment. Other solutions exist and could have been used to get further data for the research site: a

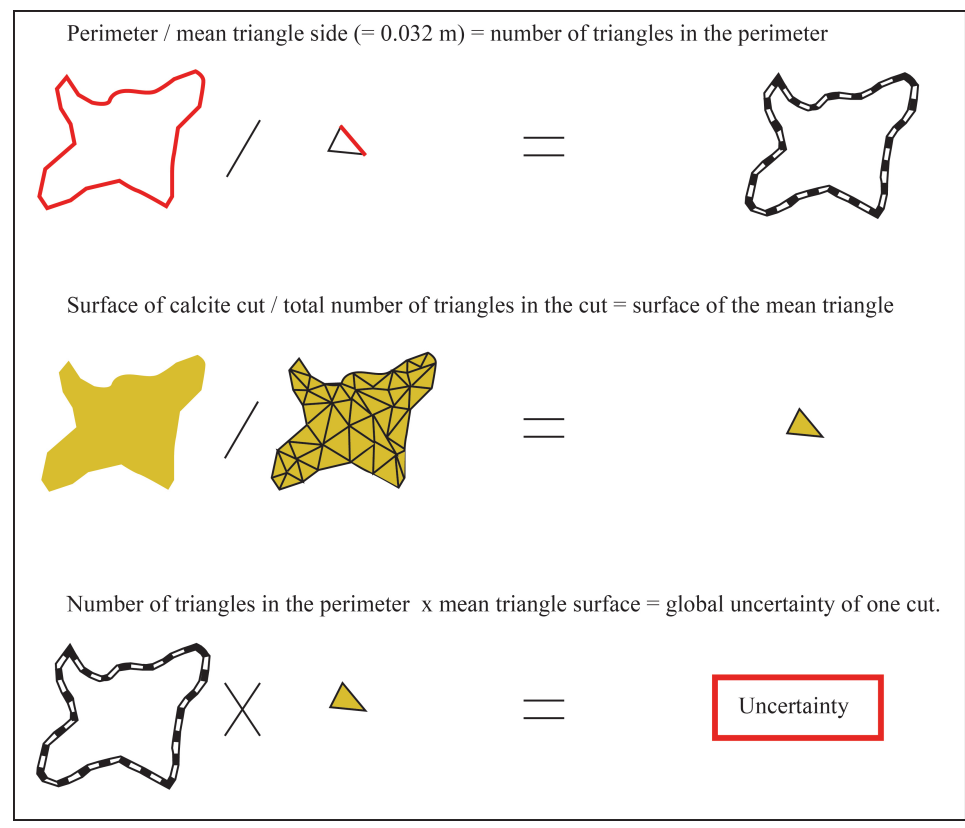

Fig. 8. Quantification of the uncertainty generated by the cutting process of the draped calcite, through the triangulated model. The final uncertainty of each cut is linked to the size of the mean triangle. subaqueous survey can be conducted with graduated sticks, and the waterfall can also be digitised with a photogrammetry method (Burens-Carozza et al., 2013) using a ring flash on the camera to suppress the shadows caused by light in a subterranean area (Plisson \& Zotkina, 2015). However, in the 360-degree topography of the subterranean canyon, geometrical differences may be more of a complicating factor compared to the scan method, and the camera has to be near the object in order to make the ring flash efficient.

We used photographs to study the past landscapes of the waterfall. However, for future data collection (beyond 2014), we intend to use laser intensity technology as a technique for monitoring and measuring the calcite evolution. Laser intensity provides information about material reflectance (Soudarissanane et al., 2007) and hence opens up the possibility of quantification of the calcite progression based on comparisons between the 2014 scan and newer ones. The point cloud will contain all the data needed to identify the calcite crust on it. However, tests have to be done regarding the impact of humidity reflection (Sadier, 2013). We assume that merging both photogrammetry and laser scanning (Habib et al., 2004) would provide a better survey with good resolution and a geometrically correct 3D model.

\section{Questioning the local cause of the surface increase}

Our photograph collection led us to observe the calcite crust's progression over time. Its quantification

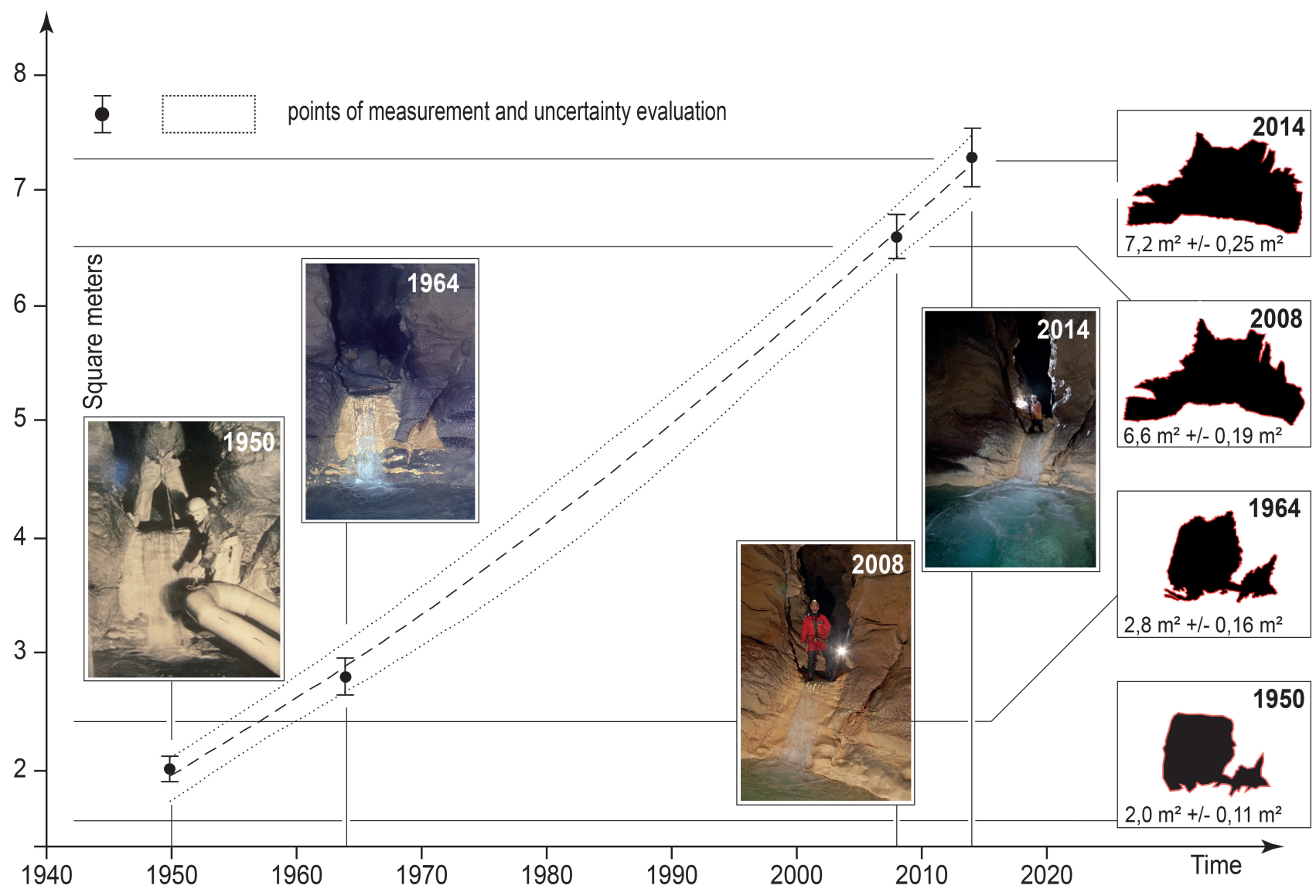

Fig. 9. Calcite crust progression over time on the first waterfall of the second access. We calculated the interpolated uncertainty with a smooth spline interpolation using the R-code package "Clam" version 2.2 (Blaauw, 2010). 
at our study site with the $3 \mathrm{D}$ model reveals that it is increasing. Since the opening of the siphon Jerome in 1992, some cavers have reported an increase in the airflow in the bottleneck parts of the cave (Lismonde, 2002). Such an increase in the airflow was also reported as the cause of an increase in the sodastraw growth rate in the neighbouring Coufin Cave (Perrette \& Jaillet, 2010). In the photograph of the calcite crust (Fig. 3b-c), no evidence of any increase in the size of laminations was observed. The expected independence of the growth rate change and the opening of the Jerome sump can be linked both to the growth mechanism of the calcareous tufa and to the size of the passages. In fact, according to Frisia et al. (2000), the tufa fabrics are associated with conditions characterised by an alternation of strong discharges and dry periods. The deposition of calcite crust was observed everywhere in the cave despite the size of certain passages that should be associated with increased airflow. Therefore, as a local factor, the opening of the Jerôme sump may not have been responsible for inducing the growth of the calcite crust.
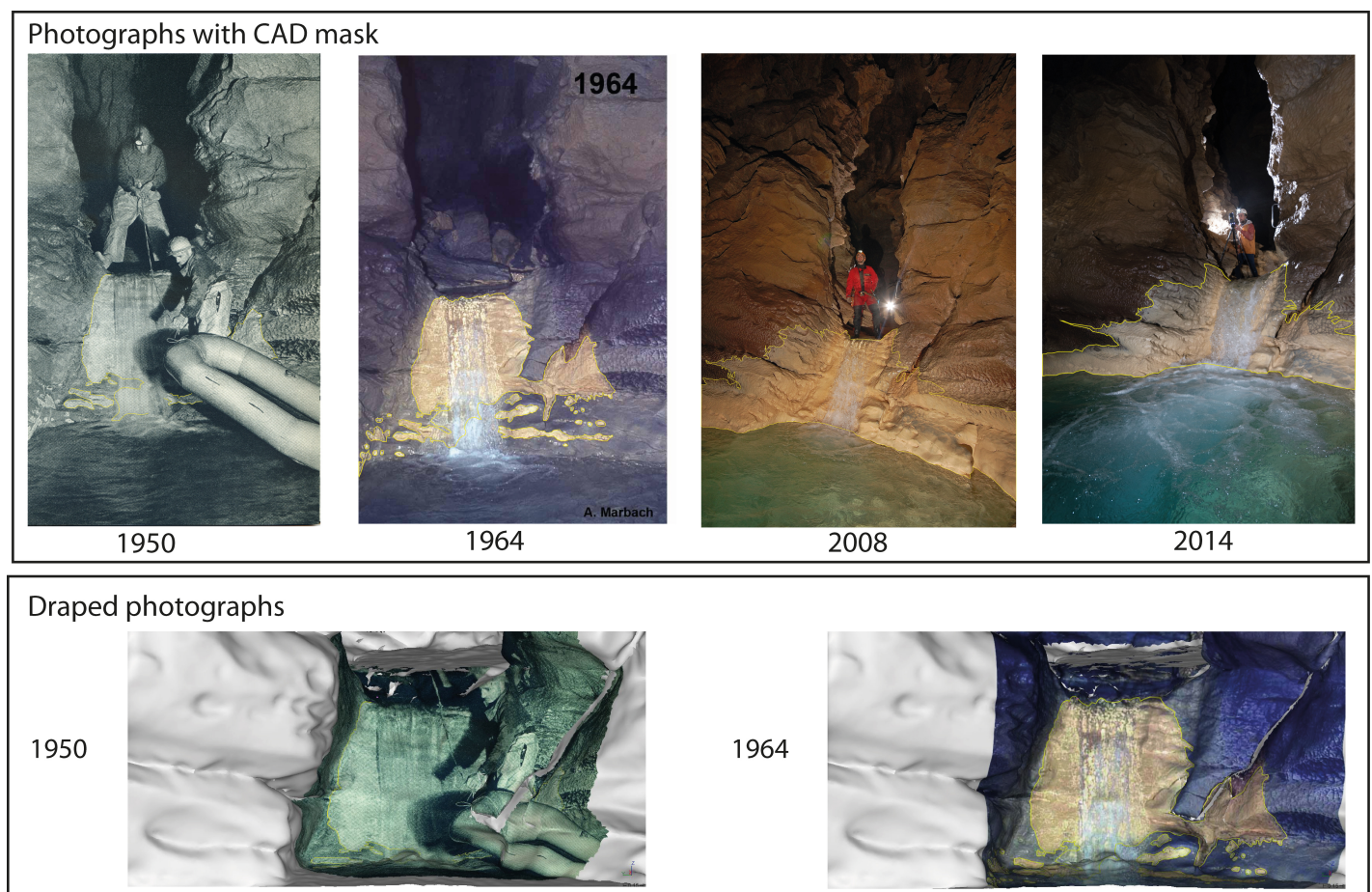

1964
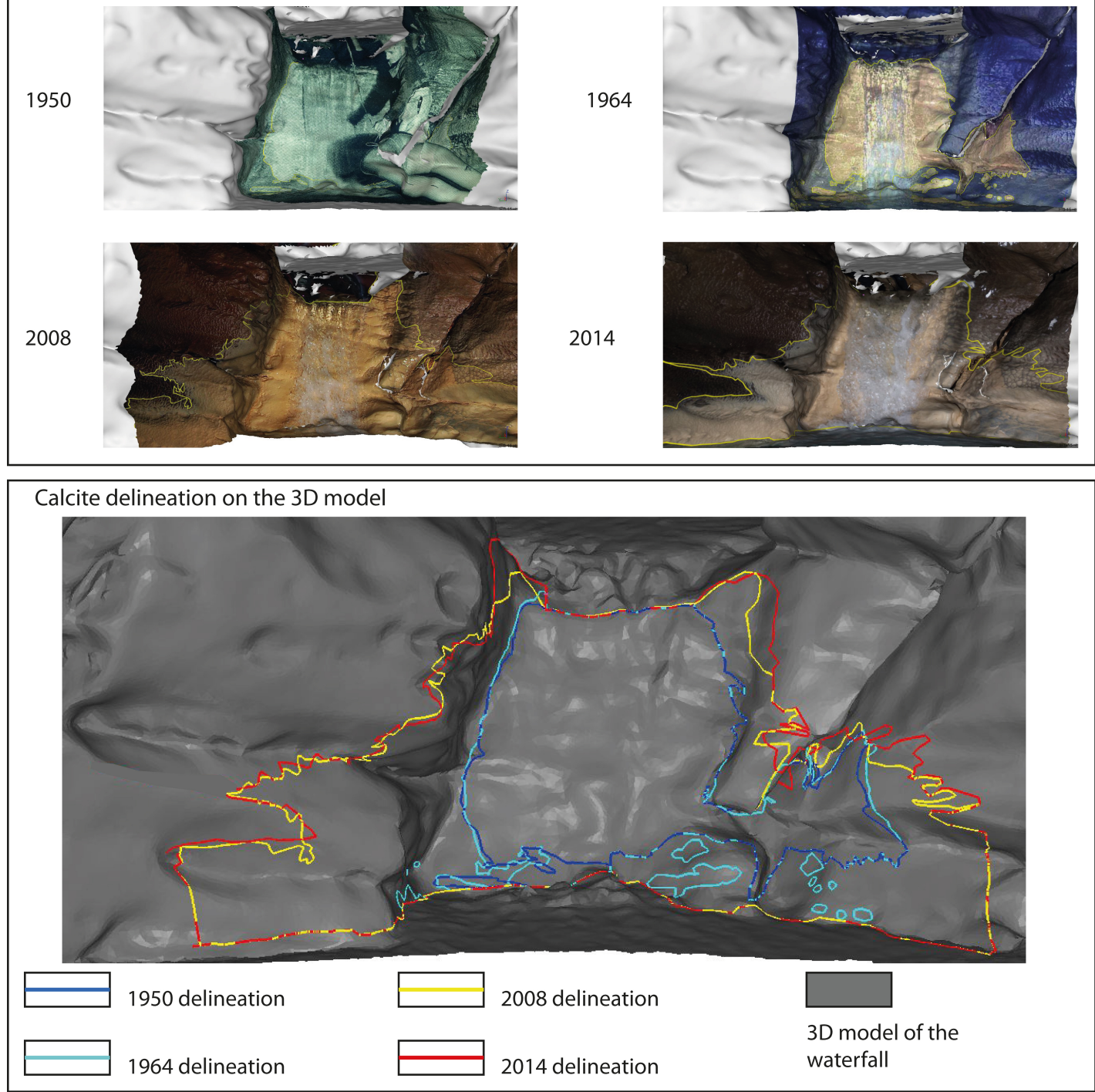

Fig. 10. Calcite delineation on 3DReshaper. The cutting process that follows the triangles was helped by a pre-delineation on the photographs, using a CAD software. The colored lines reveal the clear increase of the calcite surface through time. 
However, other factors partially linked to the perched Jérôme sump opening could have generated the acceleration in calcite growth. In fact, an increase in the airflow could slightly enhance the evaporation occurring on the walls, leading to calcareous tufa fabrics. If such a process occurred, a slight difference in growth should be observable between the narrow and the wide parts of the canyon.

\section{Environmental changes as drivers of calcite growth}

The analysis of our collection of photographs shows that the calcite surface area is increasing. Furthermore, the calcite crust was seen in the canyon before the opening of the Jérôme sump in 1992 and was already increasing. We cannot solely attribute the calcite surface area increasing to the local increase in cave ventilation in 1992, as it could have occurred prior to that. Consequently, environmental and anthropic changes must also be considered.

In the Vercors area, environmental factors are suspected to drive the calcite growth in two different ways: through increases in temperature and through changes in land cover partly due to rural decline.

First, the atmospheric reanalysis of the National Center for Atmospheric Research and National Center for Environmental Prediction (NCAR-NCEP) climatic data of the Vercors reveals a relatively warm period from 1948 to 1965 that could explain the calcite growth. That period is followed by a wet and cold period from 1965 to 1984 , which is not supposed to have produced the observed acceleration in calcite deposition. Then, a hot and dry period followed from 1984 to 2004, which corresponds to a warming of the climate. Over the last several decades, the general Vercors climate was characterised by more than $1400 \mathrm{~mm}$ rain per year. The wetness of the environment during this time could be an interesting factor influencing the increase in the growth rate. Indeed, a strong relationship has been reported between air temperature and $\mathrm{pCO}_{2}$ in soils in different mountain environments (Fairchild $\&$ Baker, 2012). Consequently, sensors have been implemented in the cave to measure the ambient temperature, the $\mathrm{CO}_{2}$ levels in air and in the water, in order to study those variations.

The second environmental parameter potentially implied in the calcite growth could be the vegetation cover increase on the plateau that has been observed since 1970, which corresponds to the end of charcoal production and timber harvesting on the plateau (Hanus, 2000). Furthermore, the cave carbonate surface area increases coincide with a change in the vegetation cover characterised by more and younger beech trees, which increase the $\mathrm{pCO}_{2}$ concentration in soils. Despite the fact that its progression has not yet been quantified, the spreading of deposition could be a result of the combination of the two environmental factors (temperature and vegetation covering) without the need of a local cause (i.e., opening of the Jerome sump and the corresponding increase in cave ventilation). However, because no quantification has yet been performed, the local cause proposed by Lismonde (2002) still needs to be considered.

\section{CONCLUSIONS}

This study presented a method designed to perform diachronic subterranean landscape analysis. Based on a collection of old photographs taken by cavers, this method draped images from different time periods onto a 3D model of the analysed subterranean landscape. The method allowed us to quantify certain changes in the subterranean landscape, such as the spatial extent of the calcite on the canyon walls. In our case, the sharp contrast between the lightly coloured calcite crust and the dark limestone wall allowed the operator to digitise the successive areas manually. As quantification of more photographs is achieved in the future, the image processing algorithm might be applied to more detailed mappings in different environments.

From an environmental point of view, we have demonstrated and quantified the growth of calcite on underground canyon walls since 1950. Two different causes of that growth have been discussed by the caver community: first, a local change induced by the opening (partial emptying) of a sump by cavers that caused an increase in airflow in the cave; and second, regional and local environmental changes. Our results show that the calcite growth preceded the opening of the sump, arguing in favour of environmental controls rather than a local effect of airflow change. Considering our current knowledge, climate and vegetation changes are probably co-factors. The local effect of a change in airflow by the opening of the Jérôme sump cannot be demonstrated even if it was involved in the increase of the surface area of calcite. The specific role of the airflow change might be more precisely ascertained only with a more complete photo collection. Indeed, this publication may encourage the collection of more photographs that could help improve the chronology of the quantification. As a development, this study should be combined with monitoring and modelling studies in order to assess the respective roles of vegetation and climate change in the calcite growth phenomenon.

\section{ACKNOWLEDGEMENTS}

We would like to thank Thibault Grandidier, Tim Pollard and Pierre Sabatier, who have helped us in all the work on karst geology and uncertainty calculations, and all the cavers who have agreed to lend us their photographs of Gournier: Serge Caillault, Patrick Degouve, Jean-Louis Guinet, Georges Marbach, Matthieu Thomas, Robert and Bernard Vidal. We are grateful for the constructive comments and suggestions of the three reviewers who improved the scientific quality of this paper.

\section{REFERENCES}

Arnaud-Vanneau A., Arnaud H. \& Thieuloy J.P., 1976 - Bases nouvelles pour la stratigraphie des calcaires urgoniens du Vercors. (Massifs subalpins septentrionaux-France). Newsletters on Stratigraphy, 5: 143-159. https://doi.org/10.1127/nos/5/1976/143 
Bourgin A., 1950 - Les rapports spéléo annuels d'André Bourgin, années 1934 à 1951. CDS Isère, paru en 1997, 334 p.

Blaauw M., 2010 - Methods and code for 'classical' age-modelling of radiocarbon sequences. Quaternary Geochronology, 5 (5): 512-518. https://doi.org/10.1016/j.quageo.2010.01.002

Burens-Carozza A., Grussenmeyer P., Guillemin S., Carozza L., Leveque F. \& Mathé V., 2013 Methodological developments in $3 D$ scanning and modelling of archaeological, french heritage site: the Bronze Age painted cave of "Les Fraux", Dordogne (France). International Archives of the Photogrammetry, Remote Sensing and Spatial Information Sciences, XL-5/W2:131-135.

https://doi.org/10.5194/isprsarchives-XL-5-W2131-2013

Caillault S. (Ed)., 2000 - TGT (Très Grande Topo): Gournier, le plus beau canyon souterrain d'Europe. Spéléo Magazine, 35, Corenc, 30 p.

Canevese EP., Forti P. \& Tedeschi R., 2013 - New acquisition, 3D modelling, and data use methods: the laser scanning survey of Re Tiberio Cave. In: Michal Filippi M. \& Bosák P. (Eds.), Proceedings of $16^{\text {th }}$ International Congress of Speleology 2015, Czech Republic, Brno, 2: 340-345.

Delannoy J.J., 1982 - Les variations spatiotemporelles de la corrosion karstique dans un massif de moyenne montagne: le Vercors. Revue de Géographie Alpine, 70: 241-255. https://doi.org/10.3406/rga.1982.2506

Delannoy J.J., Guendon J.L. \& Quinif Y., 1988 Les remplissages spéléologiques: un apport à la connaissance de la kartogénèse du massif des Coulmes (Vercors, Alpes). Annales de la Société Géologique de Belgique, 111: 21-38.

Fairchild I.J. \& Baker A., 2012 - Speleothem science: from process to past environments. John Wiley \& Sons, Chichester, $416 \mathrm{p}$.

https://doi.org/10.1002/9781444361094

Frisia S., Borsato A., Fairchild I.J. \& McDermott F., 2000 - Calcite fabrics, growth mechanisms, and environments of formation in speleothems from the Italian Alps and southwestern Ireland. Journal of Sedimentary Research, 70 (5): 1183-1196. https://doi.org/10.1306/022900701183

Frisia S., 2015 - Microstratigraphic logging of calcite fabrics in speleothems as tool for palaeoclimate studies. International Journal of Speleology, 44 (1): 1-16. https://doi.org/10.5038/1827-806X.44.1.1

Gallay M., Kan̆uk J., Hochmuth Z., Meneely J.D., Hofierka J. \& Sedlák V., 2015 - Largescale and high-resolution 3-D cave mapping by terrestrial laser scanning: a case study of the Domica Cave, Slovakia. International Journal of Speleology, 44 (3): 277-291.

https://doi.org/10.5038/1827-806X.44.3.6

Habib A. F., Ghanma, M. S. \& Tait M., 2004-Integration of LIDAR and photogrammetry for close range applications. International Archives of Photogrammetry, Remote Sensing and Spatial Information Sciences, 35 (B5): 1045-1050.

Hajri S., Sadier B., Jaillet S., Ployon E., Boche E., Chakroun A., Saulnier G.-M. \& Delannoy J.-J., 2009 - Analyse spatiale et morphologique d'une forêt de stalagmites par modélisation $3 d$ dans le réseau d'Orgnac. Karstologia, 53: 1-14.

Hajri S., 2010 - Modélisation des surfaces rocheuses naturelles à partir d'une scannerisation laser $3 D$ et extraction automatique de formes caractéristiques: Applications aux spéléothèmes et surfaces géologiques. Doctoral dissertation, Université de Grenoble, 250 p.

Hanus P., 2000 - "Je suis né charbonnier dans le Vercors". Petite histoire des hommes dans la forêt. Revue de Géographie Alpine, 88 (4): 86-87.

Jaillet S., Sadier B., Hajri S., Ployon E. \& Delannoy J.-J., 2011a - Une analyse $3 D$ de l'endokarst: Applications lasergrammétriques sur l'aven d'Orgnac (Ardèche, France). Géomorphologie: Relief, Processus, Environnements, 4: 379-394.

Jaillet S., Sadier B., Arnaud J., Azéma M., Boche E., Cailhol D., Philipponi M., Leroux P. \& Varrel E., 2011b - Topographie, représentation et analyse morphologique $3 D$ de drains, de conduits et de parois du Karst. Collection EDYTEM, 12: 119-130.

Lismonde B., 2002 - Climatologie du monde suterrain tome 2: Aérologie de systèmes karstiques. CDS Isère, Eybens, p. 97-104.

Oludare Idrees M. \& Pradhan B., 2016 - A decade of modern cave surveying with terrestrial laser scanning: $A$ review of sensors, method and application development. International Journal of Speleology, 45 (1): 71-88. https://doi.org/10.5038/1827-806X.45.1.1923

Ortega R., Maire, R., Devès G. \& Quinif Y., 2005 High-resolution mapping of uranium and other trace elements in recrystallized aragonite-calcite speleothems from caves in the Pyrenees (France): implication for $U$-series dating. Earth and Planetary Science Letters, 237 (3): 911-923.

https://doi.org/10.1016/j.eps1.2005.06.045

Perrette Y. \& Jaillet S., 2010 - Spatial distribution of soda straws growth rates of the Coufin cave (Vercors, France). International Journal of Speleology, 39 (2): 61-70. https://doi.org/10.5038/1827-806X.39.2.2

Perrette Y., Poulenard J., Saber A.I., Fanget B., Guittonneau S., Ghaleb B. \& Garaudee S., 2008 - Polycyclic Aromatic Hydrocarbons in stalagmites: Occurrence and use for analyzing past environments. Chemical Geology, 251 (1): 67-76. https://doi.org/10.1016/j.chemgeo.2008.02.013

Perrette Y., Poulenard J., Protière M., Fanget B., Lombard C., Miège C., Quiers M., Nafferchoux E. \& Pépin-Donat B., 2015 - Determining soil sources by organic matter EPR fingerprints in two modern speleothems. Organic Geochemistry, 88: 59-68. https://doi.org/10.1016/j.orggeochem.2015.08.005

Ravanel L. \& Deline P., 2011 - Climate influence on rockfalls in high-Alpine steep rockwalls: The north side of the Aiguilles de Chamonix (Mont Blanc massif) since the end of the "Little Ice Age". The Holocene, 21 (2): 357365. https://doi.org/10.1177/0959683610374887

Sadier B., 2013 - 3D et géomorphologie karstique: La grotte Chauvet et les cavités des Gorges de l'Ardèche. Doctoral dissertation, Université de Grenoble.

Soudarissanane S., Van Ree J., Bucksch A. \& Lindenbergh R., 2007 - Error budget of terrestrial laser scanning: influence of the incidence angle on the scan quality. Proceedings 3D-NordOst, p. 1-8. 